\title{
NAS president hints he may run again
}

[WASHINGTON] Bruce Alberts, president of the US National Academy of Sciences (NAS), will decide next month whether to put himself forward for a second six-year term as head of the leading US scientific body.

In a move that hints that he is preparing to stay on after his first term expires at the end of 1998, Alberts last week met Richard Klausner, director of the National Cancer Institute (NCI), to discuss how he could renew his involvement with cancer research through the NCI, which is based just outside Washington in Bethesda, Maryland.

Alberts said in an interview that he was shifting the emphasis of his leadership from science education to the promotion of international science to support sustainable development, especially in poor countries.

He added that he wanted to stay in the job, but would balance that against his desire to do research and return to his family home in California. After a review of his performance last month, Alberts said, the academy's ruling council “told me they'd like me to run for a second term, while recognising that there are personal reasons why I might not want to do so. I told them my wife and I would have a vacation in early September and come back and give them an answer."

The council will set up a committee in the autumn to decide who should be put forward for election to the presidency: in previous elections, only one name has been on the ballot sent to the academy's 1,800 members.

Alberts says that he would not be deterred from running by the NAS's continuing struggle to reverse a January court ruling that it must reorganize committee meetings of its operating arm, the National Research Council, to comply with the Federal Advisory Committee Act (FACA). The academy says the

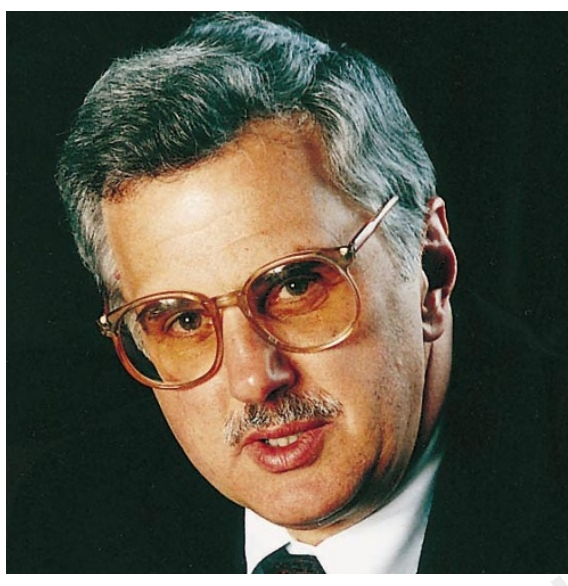

change would undermine its independence from government (see Nature 386, 309; 1997).

"I like challenges," he says. The FACA struggle is "something that makes it more likely that I will run again.” The January ruling, he says, "is so illogical that I can't imagine that it won't be fixed in the end."

Jack Gibbons, President Clinton's science adviser, said on 23 July that FACA was "a thing that you have to learn to live with, and the academy may need to live with it".

But Alberts says he has no regrets about the way in which the FACA issue has been handled, and dismisses suggestions that, instead of highlighting its damaging effects and filing an appeal to the Supreme Court, as it did last month, the NAS should have moved quietly to work within FACA's constraints.

The FACA ruling "is the most serious crisis the academy has faced in the last 10 years at least," says Alberts. It "would really mean that the independent voice of the academy would be lost."

Although the Department of Energy has halted several of its studies as a result of the

\section{Cooperative Centres fight cuts proposal}

[CANBERRA] Tony Staley, president of Australia's governing Liberal party, has challenged a government report on industrial policy that recommends cutting funding for the 65 Cooperative Research Centres. The CRC scheme forges partnerships between universities, government agencies and industry for targeted research and development.

In a letter last week to John Moore, the Minister for Industry, Science and Tourism, who commissioned the report from David Mortimer, a businessman, Staley said the cuts would "destroy the CRC programme".

The government is also investigating making CRCs "more self-funding". At present they receive an annual government budget of A \$146 million (US\$108 million), which Mortimer says should be reduced to A $\$ 20$ million and used only for "public good" research.
Staley accuses Mortimer of "lack of understanding of the CRC programme". This programme has been successful, with much of the research directed to industrial innovation, he says. Influential businessman Sir Arvi Parbo also criticized the report in a letter to the Australian Academy of Technological Sciences.

Australia's 36 universities hit out at Mortimer's view that they should depend more on funds from industry. The Australian ViceChancellors' Committee demanded the government "reject totally Mortimer's recommendations concerning R\&D”.

The committee says "swingeing cuts" to research in universities, CRCs and the Commonwealth Scientific and Industrial Research Organisation would make Australia's economic growth "critically dependent on research owned offshore". PeterPockley
FACA ruling, other departments have continued business as usual and the NRC budget - chiefly derived from government contracts - is being maintained.

"Our projected budget is the same as last year, and that surprises us because we were fearful that we'd have a major drop," says Alberts. A pay freeze imposed earlier in the year (Nature 387, 220; 1997) has been lifted and staff given an average 2 per cent increase, although senior officers' pay stays frozen. "It was my decision to take a hard line on salaries, to make sure we were protected."

Alberts acknowledges criticism of his reluctance to lobby directly for science funding, but he has no plans to "behave the same way as all of the scientific societies" by doing so. "We've been taking a broader view of how we support science than the view I think some people would like us to take," he says. But he identifies funding at the US Department of Agriculture (USDA) as a concern, and will continue to press for a sharp increase in USDA's peer-reviewed grant programme, the National Research Initiative, from $\$ 100$ million to $\$ 500$ million a year.

He also pledges to try to persuade the State Department, which has recently downgraded its scientific operations, to recognize the importance of science in international relations. He describes Tom Pickering, former US ambassador to Russia and now deputy secretary of state, as "a close friend of science".

Having started his first term in 1993 with an emphasis on the promotion of science education for the public, Alberts now says another priority - to support "sustainable development" around the world through science disseminated via the Internet - has equal billing. He says better communications mean that "we can create a completely different science" for dealing with issues such as clean water supplies. "I want the academy to take a lead on this.”

These two priorities, together with the promotion of "excellent and vigorous" science to support them both, are the three items Alberts has selected for attention in a second term, if he serves one. "Our job is to do these three over the long term, and not to get distracted by short-term issues."

This means he has no plans for bold reform in the structure of the academy itself, though issues of openness and accountability have been raised by the FACA dispute.

He says: "The main issue is not the 1,800 members of the academy. It is the million scientists in the United States, where they are and what their role is in society. That is where I will focus, not on details I can't affect and which don't really matter."

Colin Macilwain 